\title{
Learning and teaching styles: Empowering diverse learners in tertiary classrooms
}

Carisma Dreyer \& Johann L. van der Walt

Department of English Language and Literature

Potchefstroom University for CHE

POTCHEFSTROOM

\begin{abstract}
Learning and teaching styles: Empowering diverse learners in tertiary classrooms

The aim of this article is to make lecturers aware of the importance of the various elements comprising an individual learning and teaching style. Suggestions are made as to how lechurers can help their students develop a more flexible, enipowered approach to diverse learning contexts and tasks and thereby preventing "style wars". If lecturers can show students the variety and versatility of learning styles by providing experiences in different teaching styles, the resulting awareness and expansion of student learning styles may better allow students to meet the demands of academic teaching methods and assignments.
\end{abstract}

\section{Introduction}

According to Du Plessis (1993) a primary feature or characteristic of a professional person is that he/she should have undergone thorough training for the profession that he/she is entering. In general, lecturers spend much more time on teaching than on research. This is confirmed by the so-called SAPSE statistics in the RSA. And yet, most lecturers lave little or no training in tertiary teaching. Their primary interest, upon taking up their posts, was in doing research. As a result, many lecturers find themselves in a situation in which they have had little or no training for their main task, viz. teaching at undergraduate and postgraduate levels. According to Kinsella (1995), there is probably a lot more truth in saying that teachers teach the way they learned best at school/university. Lecturers may therefore select approaches and/or methods that reflect their own preferred ways of approaching academic tasks. For example, lecturers who prefer independent learning rarely integrate opportunities for students to work collaboratively, or lecturers who are auditory learners seldom remember to write key terms on the blackboard and provide graphic illustrations to help students grasp new concepts. 
Kinsella (1995:170) states that a lecturer "may indeed be highly knowledgeable, creative, charismatic, and caring, yet still be unsuccessful in educating students whose learning strengths are not acknowledged because of the teacher's fairly inflexible instructional approach. Without a fundamental awareness of our own preferences, it is easy to believe that the way we study and learn is the most efficient way and consequently bias our teaching in favour of students who approach leaming in mucl the same way we do". As each student has his/her own style, "style wars" may result (cf. Oxford et al., 1992): a mismatch between the learners' learning styles and the lecturer's teaching style.

If there is a difference between students' learning preferences and our own, the result for these students may be mediocre performance or an even more drastic one - failure. Increasingly, the university classroom is becoming multilingual, with the result that lecturers are confronted with students, in one class, who have a wide variety of learning styles. It is, therefore, crucial for all lecturers to understand, reflect, and respond to the wide range of characteristics that make students unique as learners and to have a critical awareness of their own learning and teaching preferences. Lecturers, therefore, need to create the best teachinglearning conditions possible for their students. They need to realize and give special emphasis to the realization that each individual is unique, created thus in the image of God, and should therefore be assisted to the greatest extent possible to develop their own potential through the optimal utilization of their unique learning styles. The underlying assumption behind an attitude like this is the basic Christian philosophy underlying education by committed educators who are fully aware of the fact that they are dealing with children of the covenant and who design their teaching strategies and techniques accordingly. Unfortunately, the current situation in most classrooms is that diverse learner preferences are rarely, if ever, considered in a systematic fashion.

The aim of this article is to examine some fundamental elements of an individual learning style, as well as the main characteristics of teaching styles. Suggestions for the accommodation of learning style preferences in the tertiary classroom are also made.

\section{Defining learning styles}

Exactly what does learning style mean? The literature on learning styles reveals a wide variety of definitions. Galloway and Labarca (1990:113) say: "Readers reviewing the literature on leaming styles will benefit from a high tolerance of ambiguity." Examples of definitions include:

Styles are the overall patterns that give general direction to learning behavior (Cornett, 1983). 
Learning style is the way in which each person absorbs and retains information and/or skills (Dunn, 1984).

Learning style is the biologically and developmentally imposed set of characteristics that make the same teaching method wonderful for some and terrible for others (Dunn \& Griggs, 1988).

Learning styles are cognitive, affective and physiological traits that are relatively stable indicators of how learners perceive, interact with, and respond to the learning environment (Keefe, 1979).

Learning styles are the general approaches students use to learn a new subject or tackle a new problem (Oxford et al., 1991).

The most comprehensive definition seems to be that of Kinsella (1995)

A learning style refers to an individual's natural, habitual, and preferred ways of absorbing, processing, and retaining new information and skills which persist regardless of teaching methods or content area.

\section{Elements of an individual learning style}

At least 21 components of learning style have been identified although it appears that most individuals have between 6 and 14 elements that make up their strong style preferences (Dumn et al., 1990:69). During the 1970s various researchers developed models in order to assess the wide range of elements comprising a learning style. However, most of these models can be criticized for essentially focusing on only one element among many that may influence the composition of an individual leaming style. The leaming style model developed by Dunn $e t$ al. $(1975,1979,1989)$, however, is fairly comprehensive and gives an indication of the complexity of variables that potentially influence a student's distinct approach to learning. Their approach to viewing a learning style is multidimensional and encompasses five stimulus categories: environmental, emotional, sociological, physical, and psychological. Many of the multiple elements that comprise an individual learning style are bipolar, representing a continuum from one extreme to another. However, as Kinsella (1995:171) states, "no value judgment is made about where a learner falls on the continuum". Further, these elcments are not mutually exclusive: they represent different ways of viewing complex phenomena. A brief overview of what these learning style elements entail is given in the following sub-sections

\subsection{Environmental elements}

Research indicates that regardless of their age, ability, socio-economic status, or achievement level, individuals respond uniquely to their immediate environment. For example, the amount of sound and light in a room can either help or hinder a 
student's ability to read, depending on the student's learning style preferences. Krimsky (1982) found that her students performed significantly better $(p<0,01)$ in low than in bright light (which made them restless, fidgety and hyperactive). According to Dunn and Dunn (1979) right-brain dominant students appear to prefer dim light when concentrating. Pizzo (1981) found that when the amount of sound mismatched the student's learning style, achievement and attitudes toward reading declined significantly. Besides the amount of sound and light in an environment, formal or infonnal design can also affect performance positively or negatively. Shea (1983) identified high school students with strong preferences for sitting informally on cushions, pillows, couches and carpets. When permitted to work that way, they performed significantly better $(p<0,001)$ on an English comprehension test than when they were required to sit in conventional seats. Classroom design affects at least 20 percent of secondary students for whom achievement is either increased or decreased based on where they are permitted to work (Dumn \& Dunn, 1979). If sound, light, and design can either decrease or increase a student's ability to learn during a few hours or days, the effect of these variables over prolonged periods may be powerful indeed, especially since poor achievers have been found to need exactly the opposite conditions of those prevalent in most classrooms.

\subsection{Emotional elements}

Some students function at their best in a classroom in which the atmosphere is 'emotionally charged', for example, a lecturer's use of drama and lively description as well as his own involvement and enjoyment of the material being taught (i.e., the learning atmosphere is vivid). Another example is when the lecturer allows open discussion and disagreement, and strong opinions and ideas are stated and defended. However, some students function better in a classroom where the emotional tone is low-keyed and relatively neutral. In such a classroom the lecturer focuses on the task at hand in an objective manner, minimizing his own emotional involvement and focusing on leading the students to intellectual involvement and analysis. Students with this type of leaning style very often feel threatened in a classroom with a 'high' emotional atmosphere. According to Dunn and Dunn (1979) students who are not motivated, persistent, or responsible should be taught differently from those who are. Motivated, persistent, responsible students need to be told what they are required to learn (e.g., objectives or tasks), what they may use as resources and how they may demonstrate their acquired knowledge or skill. They welcome praise and feedback when the assignment has been completed (Dumn \& Dunn, 1979). The unmotivated (those not persistent and responsible) require slort assigninents or fewer objectives at a time, frequent feedback, a great deal of supervision and praise as they are working. 


\subsection{Sociological clements}

How students respond to other people also contributes to the selection of a method through which they are likely to achieve. Some work and learn best alone; they are distracted by the presence, movements or sounds of others. To these students the inclusion of small-group tasks may be an unwelcome intrusion in daily classroom activities. Many of these students report considerable trepidation about collaborating with classmates. A reason for this may be the traditional, hierarchical South African educational system which regards the lecturer as an unquestioned authority on subject matter. Students, therefore, rarely express their own opinions and never question what the professor says. Students may, as a result, not place much value on class discussions where classmates share and construct knowledge (cf. Kinsella, 1995). Many students, on the other hand, achieve best when among their peers, for them team learning, case studies, brainstorning and other small-group techniques tend to facilitate learning. Research has also shown that some students work better with media than with people or with computers (Martini, 1986). It is also true that some students can learn well in any combination - alone, with others, or with media (Dunn \& Dunn, 1979)

\subsection{Physical elements}

We all know early birds, night owls, and people with either high- or low-energy levels at different times of the day or evening. Research demonstrates that no matter when a class is in session, it is the wrong time of day for almost one-third of that population (Freeley, 1984)

The sensory preferences (visual vs auditory vs hands-on or tactile-kinesthetic) of learners are the physical, perceptual learning channels with which they most easily learn (Oxford et al., 1991). Visually oriented students enjoy reading and need a great deal of visual stimulation (e.g., transparencies, videos, computers, chalkboard and posters). For them, lectures, conversations, and oral directions without any visual backup are very confusing and can be anxiety-producing. Visual learners prefer to have written assignments, and it is wise if the lecturer provides written evaluation. Auditory students, unlike visual students, are comfortable with lectures, discussions, radio and television. Tutorials, for example, may provide these learners with additional opportunities to process information aloud for themselves. Hands-on students like manipulative and threedimensional materials that are touchable and moveable. Sitting at a desk (the typical academic posture) for very long is uncomfortable for them; they would rather sit on the floor or on a couch. They need frequent breaks and, above all, physical action (e.g., games and dramatic activities). 
Hodges (1982:30-31) has demonstrated that "approximately $90 \%$ of traditional classroom instruction is geared to the auditory learner. Teachers talk to their students, ask questions, and discuss facts. However, ... only $20 \%$ to $30 \%$ of any large group could remember $75 \%$ of what was presented through discussion". Reid (1987) noted that $90 \%$ of traditional college classroom instruction is geared to the auditory leamer, who is in the minority anong many language groups. If it is true that $90 \%$ of all instruction is conducted through either lecture or lecturediscussion, it is no wonder that so few students achieve as well as they should.

Kinsella (1995:173) states that, as students grow older in terms of academic achievement, those with mixed modality strengths have a decidedly better chance of success than do those with a single modality strength because they can process information in whatever way it was presented. Unfortunately, however, less flexible learners are rarely accommodated in the traditional tertiary classroom. A student's perceptual strengths and weaknesses are extremely important, for no matter how motivated a student might be, inability to absorb and retain through an inappropriate sense tends to dampen motivation and, certainly, inhibits achievement.

\subsection{Psychological elements}

Students with a global leaming style seek the big picture right away. This kind of learner sometimes has trouble discerning the important details from a confusing language background. Global leamers usually choose holistic strategies such as guessing, predicting, searching for the main idea, and engaging in extensive communication in English (Oxford et al., 1992). Global leamers are especially effective in situations where collaboration and social relationships contribute to achievement (Witkin et al., 1977). Global learners may, therefore, experience problems when they are required to independently analyze the components or steps in a task, or do assignments with a "trial-and-error" or "discovery" approach. According to Violand-Sanchez (1995) these students also respond with greater enthusiasin to course content and activities that are clearly structured, and related to their personal experiences and interests.

In contrast, analytic students like details better than the overall picture. The analytic student has no trouble picking out significant details from a welter of background items and prefers language leaming strategies that involve dissecting and logically analyzing the given material, searching for contrasts, and finding cause-effect relationships. The analytical learner very often dislikes excessive input; they respond to selective, low-intensity stimulus (cf. Kinsella, 1995). According to Chapelle and Roberts (1986) analytical students do well in tests of grammatical accuracy. 
According to Ellis (1989) the analytic student might naturally prefer to engage in formal language learning aimed at achieving accuracy, while the global student might prefer learning that is aimed at and takes place through communication. Research (e.g. Douglass, 1979) indicates that both groups learn equally well but achieve significantly higher scores when taught in a style that is correct for them When one considers traditional classroom teaching, it would seem as if the analytical environment has the upper hand: teaching is organized to promote individual autonomous achievement and where verbal and analytical skills are the primary gauges of intelligence.

Another related dimension of learning style concerns impulsivity and reflection, with impulsive students being more global and reflective students being more analytic. Impulsive students show quick and uncritical acceptance of initially accepted hypotheses. Overly inpulsive students can be error-prone, both in the productive skills of writing and speaking and in the receptive skills of listening and reading. Reflective students prefer systematic, analytic investigation of hypotheses, and are usually accurate in their performance of all skills (Oxford $e t$ al., 1992).

Every healthy individual uses some combination of both left- and right-brain behaviours, but most people show a preference for one or the other. The leftbrain learner is often called linear (likes to process information line-by-line, or in a sequence), or analytical (likes to look logically at details and facts). The rightbrain preference individual is called a global leamer because that person sees the big picture and processes information as a whole. The left-brain learner is usually more logical, organized, and disciplined. This person wants a "plan", likes to look at details, and makes decisions by facts. The right-brain learner likes things to be informal and spontaneous, is usually creative, and tends to make many decisions based on intuition and feelings. Left-brain learners can apply new information quickly, and usually prefer to work alone. Right-brain learners need longer to assimilate material and often prefer to work with others.

Once again it would seem as if our educational system operates as if students had only the left-brain hemisphere. In traditional high school and university classes, students are largely expected to master new material through listening to lectures and discussions, reading textbooks, and completing written assignments. It can be that students who favour right-hemisphere processing may experience a "style conflict". For example, these students will find it difficult to master course content, even though well-structured, which contains few illustrations, examples and analogies 
Learning and teaching styles: Enpowering diverse learners in tertiary classrooms

\section{Lecturers and their teaching styles}

At a number of universities in South Africa lecturers have been evaluated in an effort to isolate those characteristics that produce effective instruction. In many cases, these efforts have been misdirected by weaknesses both in their assumptions and their basic designs. Those deficiencies include:

* Difficulties in accurately identifying common positive characteristics of lecturer personality and style.

* Incorrect assumptions about what ought to be measured when observing classroom teaching.

* A lack of understanding that lecturers may be knowledgeable, charismatic, dramatic, hard-working, caring, and dedicated, and still not be effective with students whose leaming styles are not complemented by their teaching styles.

Just as there are many learning styles, theie are also identifiable teaching styles. However, there is no single correct style of teaching. The ideal is that lecturers should adapt their teaching to each specific teaching and learning situation. This will have the effect that a variety of teaching methods and approaches will have to be followed by each lecturer in order to achieve a range of aims and to accommodate students with differing needs and learning orientations. Historically, it was assumed that if one followed a recognized method of good teaching, most students would learn. The percentage of students who did learn and were awarded degrees was sufficiently high to perpetuate this belief. However, the recent focus on remedial programmes, mentoring systems, individualized instruction and the emphasis on the lowering of failure rates should force us to reexamine teaching styles and their relative merits

Various categorizations of teaching orientations and teaching styles have been made. The following teaching styles have been identified by Axelrod (1973) and Fischer and Fischer (1979)

* The subject-centred style

* The lecturer-centred style

* The student-intellectual centred style

* The student-as-person centred style

* The emotionally exciting and its counterpart

\subsection{The subject-centred style}

The lecturer with this approach is of the opinion that his primary teaching task is to outline the content of the subject logically and systematically in the classroom to enable students to master the material. By "covering the subject", they satisfy 
their consciences even if little learning takes place. The good student here is one who is able to master the facts and the principles of the subject discipline well and to regurgitate it to the satisfaction of the lecturer. In the classes offered by this lecturer, interaction is limited to the subject field. In the classes there is not really room for personal opinion, and the teaching is done mainly according to the lecture method. The method does not change even if the year group and the class size might vary.

\subsection{The lecturer-centred style}

The lecturer with this approach to teaching regards himself as the ideal role model for students with regard to the practice of scholarship. He regards the classes which are offered as a demonstration and would, as it were, like to invite students to emulate the intellectual process that he is demonstrating. Knowledge is largely regarded as process and not so much as product. Lecturers with this style who teach the same subject can teach in a wide divergence of styles, because the lecturer and the process are very prominent. The teaching method is mostly lecturing, in which students are encouraged to ask questions. In the answer to the questions the lecturer again uses the opportunity to demonstrate how wellinformed he is and how he approaches problem-solving

\subsection{The student-intellectual centred style}

The lecturer with this approach sees the intellectual growth of the student as the main purpose. The process of scientific investigation is of great importance - and not so much the facts and principles of the field in question. Teaching methods and learning experiences are chosen in such a way that students are taught to think and their curiosity is stimulated. The activity of the student assumes an important place in the teaching/learning situation and the problem-solving approach is visible. Assignments to students attempt to motivate them to independence and intellectual maturity.

\subsection{The student-as-person centred style}

A lecturer with this teaching style has as primary aim of the teaching the personal, social and intellectual development of the student. The intellectual development is seen as part of the total development of the student. Class meetings are characterized by intensive interaction and discussions are informal and frank. The lecturer mostly plays the role of counsellor or source of information. The student is seen as an individual who has to attain insight and assume responsibility for his own behaviour and aims. Assignments to students aim at problem-solving along new ways, and also at self-expression. Self-evaluation is frequently used by these lecturers. 
Learning and teaching styles: Empowering diverse learners in tertiary classrooms

\subsection{The emotionally exciting and its counterpart}

These lecturers show their own intensive emotional involvement in teaching. They enter the teaching/learning process with zeal and usually produce a classroom atmosphere of excitement and high emotion. Their counterparts conduct classrooms subdued in emotional tone, where rational processes predominate, and the learning is dispassionate though just as significant as in the classrooms of the emotionally involved lecturers.

Despite the supportive evidence in favour of the importance of learning and teaching style "wars" and "flexing", many lecturers remain unaware of the extent to which learning style characteristics contribute to individuals' ability to absorb and retain new or difficult information or skills.

\section{Accommodating diverse learning style preferences in the tertiary classroom}

All the information generated about learning styles will be of little use to us as lecturers unless we can somehow apply it to the classroom and our way of teaching. Should we accommodate students' learning styles or not? If we agree that we should accommodate students' learning styles, where do we begin? If we tried to match every student with the lecturers available it could become an administrative nightmare.

If the concept of learning style accommodation and development is going to have practical value for the average classroom practitioner, lecturers must have ways of identifying their own as well as their students' learning preferences that are easily administered and that produce reliable data. Various instruments are available for this purpose (cf. Kinsella's Perceptual Learning Preferences Survey and Classroom Work Style Survey; Oxford's Style Analysis Survey; Reid's Perceptual Learning Style Preference Questionnaire). However, assessing learning styles with these or other instruments should not stigmatize or pigeonhole students but instead provide avenues to foster intellectual development and lifelong learning. After assisting the students in identifying their individual learning preferences the lecturer should now try to provide an environment that facilitates the identification by students of the learning and study strategies that work best for them.

The role of the lecturer cannot be underestimated in a classroom that purports to promote diversity. The classroom environment hinges on the attitude of the lecturer; lecturers must be willing to look at their own learning/teaching styles objectively before they can be non-judgmental with their students. Lecturers who are unaware of learning/teaching style dynamics may unconsciously watch for thinking pattenss similar to their own, and penalize students who use processes 
that are dissimilar (Claxton \& Ralson, 1978). A study by James (1973) showed that teachers gave higher course grades to students with learning styles most similar to their own teaching style, and they believed these students understood the material better, when in fact the differences were not significant.

Since there is evidence that students with greater learning style flexibility are also greater achievers (Kirby, 1979), our goal as lecturers should be not only to make use of a variety of activities but also to encourage students to develop in their weaker areas. As Witkin et al. (1977:12) state, the "development of greater diversity in behaviors within individuals seems as important an objective as the recognition and the utilization of diversity among individuals". Scarcella and Oxford (1992) also emphasize the importance of "stretching the comfort zones" of the learner. Even if we could identify and remember each student's preferred learning style, we would certainly set a dangerous precedent if we were to label students by their learning preferences and teach only to those preferences. While all students should have ample opportunity to learn through their preferred style they also need to be open to the idea of "style flex" - that is, students should be encouraged to diversify their style preferences (Wallace \& Oxford, 1992). Similarly, lecturers must assess their own learning and teaching styles and work toward "flexing" these styles. As Mosston and Ashworth (1990:3) state: "Skilful teaching is the ability to move deliberately from style to style as the objectives change from one teaching episode to another." What we are saying, therefore, is that learning style preferences vary anong individuals and that efforts should be made firstly, to understand these differences and secondly, to alter teacher style in those areas and at those times that inodifications are possible.

If students come from an educational background where education is heavily teacher-directed, knowledge of their individual learning style preferences could help them to assume responsibility for their own learning by helping them select learning strategies that build on their innate preferences (Rossi-Le, 1995). For students conditioned via a "banking concept of education", as postulated by Freire (1970), to be passive recipients of teacher informational deposits, learning styles and student responsibility could be a revolutionary idea and one to which they might need to be guided.

Most of the learning style elements can be accommodated fairly easily by developing students' awareness of their own styles, permitting some flexibility, and then gradually developing the types of resources that complement learning styles that appear not to flourish in a conventional tertiary teaching setting. For example, the environmental and enotional elements of an individual learning style can be accommodated by any lecturer - regardless of teaching style, as long as the phenomena are understood, and the lecturer is willing to permit some flexibility. With regard to the sociological elements lecturers need to become 
Learning and teaching styles: Empowering diverse learners in terfiary classrooms

competent in handling various pair and group-related activities (e.g., pair work, group work, brainstorming, horse-shoe groups, cross-over groups, etc.).

The handling of physical and psychological learning style preferences in the classroom is very important. Having identified his/her own learning style preference the auditory leamer will now know what his/her leamer characteristics are, for example, these students may not read assigned cliapters, articles, or stories thoroughly, in hopes of having the main ideas clarified by a class lecture or discussion; they often feel frustrated when lecturers write assignment and test instructions on the blackboard or on a handout but do not go over them orally. Once familiarized with teaching practices that complement their learning styles, students will better be able to articulate their needs to the lecturer. For example, the auditory learners will now be able to ask the lecturer to give oral summaries of the main points in lectures or assigned readings, or they may ask for tutorials as additional opportunities to process information aloud for themselves (i.e., teaching strategies). Once they are capable of this they can be taught certain strategies that will help them to process information through their preferred modality strength, for example, the auditory learners can make tape recordings of any information they want to leam and play it back to themselves wherever they go, or they can find a "study buddy" with whom they can discuss class material and prepare for tests (study strategies) (cf. Kinsella, 1995). These students will have acquired not only more English language proficiency but also the tools for learning other subjects.

\section{Conclusion}

We make the assumption that most human beings can be changed, and therefore, to some extent at least, both learning and teaching styles can be modified. It is our further belief that as professionals, lecturers must be willing to examine and to alter their teaching styles if evidence warrants such change. For example, Wallace and Oxford (1992) found that students and lecturers experienced style conflicts $82 \%$ of the time. The lecturer with a clear indication of his own style can make better adjustments in order to effect better learning in his students. Lecturers should try to provide a variety of learning experiences to accommodate the various learning styles that exist in the average classroom. Then all students will have at least some activities that appeal to them based on their learning styles, and they are more likely to be successful in these activities. The feeling of success will be a motivating factor for additional leaning. A lecturer who creates a truly "leamer-centred" classroom understands and respects the diversity of learning strengths within any group, and offers choices in how information and skills will be acquired. 
References

AXELROD, J 1973. The university teacher as artist San Francisco : Jossey Bass

CHAPELLE, C.A. \& ROBERTS, C 1986. Ambiguity tolerance and field independence as predictors of proficiency in English as a second language Language Learning, 36:2745 .

CLAXTON, C. \& RALSON, Y 1978 Learning styles: their impact on teaching and administration (AAHE-ERIC Higher Education Report No 10). Washington, DC American Association for Higher Education

CORNETT, C.E. 1983. What you should know about teaching and learning styles. Bloomington, IN : Phi Delta Kappa

DOUGLASS, C.B 1979. Making biology easier to understand. American Biology Teacher, 41(5):277-299.

DUNN, R. 1984. How should students do their homework? Research vs. opinion. Early Years, 14(4) 43-45

DUNN, R S \& DUNN, K J 1979. Learning styles/teaching styles: Should they ... Can they Be matched? Fducational Leadership, 36:236-244.

DUNN, R S. \& GRIGGS, S.A. 1988. Learning styles: Quiet revolution in American schools Reston, VA : National Association of Secondary School Principals.

DUNN, R, DUNN, K \& PRICE, GE 1975. The learning style inventory. Lawrence, KS. Price Systems.

DUNN, R, DUNN, K. \& PRICE, G.E 1979. Identifying individual learning styles. (In Keefe, J.W ed Student learning styles: Diagnosing and prescribing programs. Reston, VA. : National Association of Secondary School Principals. p. 39-54.)

DUNN, R., DUNN, K \& PRICE, G.E 1989. Learning Styles Inventory (LSI): An inventory for the identification of how individuals in grades 3 through 12 prefer to learn. Lawrence, KS. Price Systems

DUNN, R, GEMAKE, J , JALALI, F. \& ZENHAUSERN, R. 1990 Cross-cultural differences in learning styles of elementary age students from four ethnic backgrounds Journal of Multicultural Coumseling and Development, 18:68-93.

DU PLESSIS, S J P 1993 Handboek vir dosente Potchefstroom : Departement Sentrale Publikasies

ELLIS, R. 1989 Classroom learning styles and their effect on second language acquisition: a study of two learners. System, 17:249-262

FISCHER, B \& FISCHER, L. 1979. Styles in teaching and learning Educational Leadership, 36:245-254

FREELEY, ME 1984 An experimental investigation of the relationships among teachers' individual time preferences, inservice workshop schedules, and instructional techniques and the subsequent implementation of learning style strategies in participants' classroom St John's University (Doctoral dissertation.)

FREIRE, P 1970 Pedagogy of the oppressed New York : Seabury

GALLOWAY, V \& LABARCA, A 1990 From student to learner: style, process, and strategy. ( $I n$ Birchbichler, D W. ed. New perspectives and new directions in foreign language education Lincolnwood, $1 \mathrm{~L}$. : National Textbook Co and ACTFL. p 111158.)

HODGES, H 1982. Madison-prep-Alternatives through learning styles. (In Keefe, J W ed Student learning styles and brain behavior: Programs, instrumentation, research Reston, VA : National Association of Secondary School Principals p 28-32.)

JAMES, C D R. 1973. A cognitive style approach to teacher-pupil interaction and the academic performance of black children New Brunswick, NJ. : Rutgers University. (Master's thesis.)

Koers 61(4) 1996:469-482 
Learning and feaching styles: Enmpowering diverse learners in tertiary classrooms

KEEFE, J.W 1979 Student learning styles: diagnosing and prescribing programs. Reston, VA. : National Association of Secondary School Principals.

KINSELLA, K 1995. Understanding and empowering diverse learners in ESL classrooms. (In Reid, J.M. ed Learning styles in the ESL/EFL classroom. Boston : Heinle \& Heinle. p 170-194.)

KIRBY, P. 1979. Cognitive style, learning style, and transfer skill acquisition. (Information series No. 195.) National Center for Research on Vocational Education. Columbus : Ohio State University.

KRIMSKY, J.S. 1982 A comparative analysis of the effects of matching and mismatching fourth grade students with their learning style preferences for the environmental element of light and their subsequent reading speed and accuracy scores. St. John's University. (Doctoral dissertation.)

MARTINI, M. 1986. An analysis of the relationship between and among computer-assisted instruction, learning style perceptual preferences, attitudes, and the science achievement of seventh-grade students in a suburban New York school district St. John's University. (Doctoral dissertation.)

MOSSTON, M. \& ASHWORTH, S 1990. The spectrum of teaching styles: From command to discovery. New York : Longman.

OXFORD, R, EHRMAN, M \& LAVINE, RZ 1991 Style wars: teacher-student style conflicts in the language classroom (In Magnan, S.S. ed. Challenges in the 1990s for the college foreign language programs Boston, MA : Heinle \& Heinle. p 1-25)

OXFORD, R.L., HOLLAWAY, M E. \& HORTON-MURILLO, D 1992. Language learning styles: Research and practical considerations for teaching in the multicultural tertiary ESL/EFL classroom. System, 20(4):439-456.

PIZZO, J 1981. An investigation of the relationships between selected acoustic environments and sound, an element of learning style, as they affect sixth grade students' reading achievement and attitudes. St. John's University. (Doctoral dissertation.)

REID, J 1987. The learning style preferences of ESL students. TESOL Quarterly, 21:87. 111

ROSSI-LE, L. 1995 Learning styles and strategies in adult immigrant ESL students (In Reid, J. ed Learning styles in the ESL/EFL classroom. Boston : Heinle \& Heinle p. 118-125.)

SCARCELLA, R. \& OXFORD, R 1992. The tapestry of language learning: The individual in the communicative classroom. Boston, MA : Heinle \& Heinle.

SHEA, T.C. 1983. An investigation of the relationship among preferences for the learning style element of design, selected instructional environments, and reading achievement of ninth grade students to improve administrative determinations concerning effective educational facilities. St. John's University. (Doctoral dissertation.)

VIOLAND-SANCHEZ, E 1995 Cognitive and learning styles of high school students Implications for ESL curriculum development. (In Reid, J ed. Learning styles in the ESL/ EFL classroom. Boston : Heinle \& Heinle. p. 48-62.)

WALLACE, W. \& OXFORD, R. 1992 Disparity in learning styles and teaching styles in the ESL classroom: Does this mean war? AMTESOL Journal, 1:45-68.

WITKIN, H.A., MOORE, C., GOODENOUGH, D. \& COX, P. 1977 Field dependent and field independent cognitive styles and their educational implications. Review of Educational Research, 47: 1-64. 